\title{
Młodzież i młodzi dorośli wobec kryzysu indywidualnego - potrzeba wsparcia społecznego w rozwoju psychicznej niezależności (i dojrzałej tożsamości)
}

\section{KEY WORDS}

adolescent, young adult, crises, support, psychological independence, mature identity

\begin{abstract}
Suchodolska Jolanta, Młodzież i młodzi dorośli wobec kryzysu indywidualnego - potrzeba wsparcia społecznego w rozwoju psychicznej niezależności (i dojrzałej tożsamości) [Adolescents and Young Adults Facing Individual Crisis - The Need for Social Support in Independent and Mature Psychological Identity Development]. Kultura Społeczeństwo - Edukacja nr 2(10) 2016, Poznań 2016, pp. 231-247, Adam Mickiewicz University Press. ISSN 2300-0422. DOI 10.14746/ kse.2016.10.18.

The study refers to the problem of the presence of the crisis in psychosocial development of young people - adolescents and young adults. Both the youth and young adults go through numerous, naturally present in human development, moments of increased tension resulting from the appetite for independence and self-sufficiency. This seems to be a common feature for both groups; both adolescents and young adults experience the burden due to overlapping obligations and commitments made to oneself and to the world and which comes from the specific social roles they assume as well as the development - related tasks they perform. The challenges are taken up to find self-fulfillment in numerous new roles, to achieve ambitions of everyday life as well as the future ones. Not surprisingly, in this period a man is believed to be, on the one hand, exposed to the experience of crisis (relating to the search for oneself and one's own place in life, in social relationships and professional life) and, on the other hand, a young adult most intensely makes its network of social support for further years. In the study, the author refers to the research in which young adults confirm the presence of the crises in their lives. They identify and name these crisis situations and formulate their expectations of the sources and forms of support in the crisis.
\end{abstract}


U źródeł każdego kryzysu leży pytanie o to, kim jesteś i jak żyjesz. Tego „kryzysowego pytania” chciateś uniknać, tłumiąc problem. Tylko wtedy, gdy pozwolisz, by naprawde dotarło do Ciebie to pytanie, i będziesz chciat poszukać na nie odpowiedzi, rzeczywiście zmierzysz się z kryzysem.

A. Downs

Kryzys w życiu człowieka może się pojawić w każdym momencie, zarówno $\mathrm{w}$ warunkach permanentnego zmęczenia, deficytu wypoczynku, słabych relacji społecznych, jak i w sytuacjach przewlekłego stresu, prowadzącego do zaburzenia cyklu rozwojowego człowieka, generującego uczucie lęku i wyobcowania ${ }^{1}$. Ponadto można powiedzieć, że kryzys - jako zjawisko psychologiczne - na ogół wiąże się też z sytuacją podejmowania decyzji, $\mathrm{w}$ której konieczne jest działanie pod presją czasu $^{2}$. Zgodnie ze stanowiskiem klasyków - E. Lindemana i C. Caplana - kryzys jest także swoistą reakcją człowieka zdrowego, na ogół funkcjonalnie przystosowanego na sytuację trudną, nagłą, nieprzewidzianą i przekraczającą ludzkie doświadczenie, wobec której dotychczasowe zasoby i umiejętności rozwiązywania problemów stają się niewystarczające (Kubacka-Jasiecka 2007: 246). W tym ujęciu kryzys jest trwającym przez pewien czas stanem nierównowagi, związanym $\mathrm{z}$ wysokim poziomem dystresu i niezdolnością radzenia sobie. Uważa się, że charakterystyczne są dla niego specyficzna symptomatologia i przebieg. Najczęściej wywołany bywa przez różne wydarzenia krytyczne, określane także jako czynniki zmiany życiowej. O kryzysie mówi się potocznie, że jest odpowiedzią na pojawiającą się przeszkodę, która znacznie utrudnia bądź uniemożliwia osiągnięcie ważnych dla jednostki celów życiowych; dotyczy osobistych trudności lub sytuacji, które uniemożliwiają świadome kontrolowanie własnego życia oraz odbierają ludziom zdolność sprawnego działania i funkcjonowania w rzeczywistości społecznej. Ponieważ, korzystając ze standardowych metod rozwiązywania problemów, przeszkody tej nie da się usunąć ani pokonać, trwanie w kryzysie powoduje stan dezorganizacji i poczucia egzystencjalnego chaosu. Wówczas sytuacje wywołujące kryzys wydają się nie do pokonania, co sprawia, że dotknięta nim osoba czuje się bezradna. Poczucie tej bezradności i braku kompetencji do działania, ograniczające poczucie bezpieczeństwa emocjonalnego, w sposób obiektywny generują brak możliwości poradzenia sobie. Podejmując kwestie występowania zjawisk kryzysowych w życiu człowieka, warto zaznaczyć, że pojawiają się one na różnych etapach funkcjonowania społecznego i traktować je należy jako naturalne, nieodłączne elementy ludzkiego życia. Z tego też powodu nie sposób ich uniknąć (Kubacka-Jasiecka, 2007).

\footnotetext{
${ }^{1}$ Szerzej: James, Gilliland 2008
}

${ }^{2}$ Szerzej: Badura-Madej, 1999. 
Z perspektywy rozważań nad funkcjonowaniem społecznym młodych dorosłych interesuje mnie ujęcie kryzysu reprezentowane przez Erika Homburgera Eriksona, rozumiane w kontekście obecnych w rozwoju momentów sensytywnych, towarzyszących poszczególnym fazom rozwoju³. Ilustruje ono kryzys jako naturalny moment przesilenia, związany z trudnością podejmowania ważnych życiowo decyzji i przeżywanych wraz z nimi rozterek. W sytuacjach tak rozumianego kryzysu ważne jest jego rozpoznanie i nabycie odpowiednich umiejętności poradzenia sobie, adekwatnych do sytuacji i dotychczasowych kompetencji osobistych. Na każdym etapie rozwoju dość oczywiste jest, że przybierać może on inny wymiar, ze względu na towarzyszące podłoże psychospołeczne i zróżnicowane szanse rozpoznania kryzysu przez środowisko oraz uzyskanie od niego pomocy. W okresie młodości związany jest najczęściej z próbą budowania niezależności w ważnych dla młodego człowieka kwestiach życiowych. W tym okresie życia sposoby reagowania emocjonalnego i społeczne funkcjonowanie młodych ludzi charakteryzują się dużym zróżnicowaniem indywidualnym. Mają na to wpływ między innymi czynniki społeczno-kulturowe, zdrowotne oraz społeczno-ekonomiczne. Nierzadko źródłem rozwijającego się kryzysu jest brak zadowolenia $\mathrm{z}$ aktualnej sytuacji życiowej $\mathrm{w}$ takich ważnych wymiarach, jak: relacje i bliskie związki, edukacja, obszary samorealizacji oraz planowanie przyszłości. Inną ważną kwestią jest podejmowanie skutecznych prób formowania własnej, autonomicznej tożsamości. Według Erika H. Eriksona ma to na celu wypełnienie przestrzeni moratorium psychospołecznego, którego zakres i możliwe formy realizacji zmieniają współcześnie swój obraz, głównie z powodu transmisji społecznych wartości granicy owego moratorium. Szansa na przesuwanie się moratorium (często z powodu braku psychicznej gotowości do podejmowania ważnych życiowo decyzji i za zgodą dojrzałego społecznie środowiska) sprzyja tworzeniu się zasobów młodych ludzi w obszarach nowych doświadczeń i kompetencji. Okres wczesnej dorosłości sprzyja potrzebom tworzenia indywidualnych biografii (w tym także rozwojowi nowych zdolności psychospołecznych i komunikacyjnych), kształtowanych w konfrontacji z ich dotychczasowymi doświadczeniami w zakresie własnej zaradności, także oczekiwań i układów konstruowanych wewnątrz społeczeństwa. $Z$ tej perspektywy niezwykle ważne wydają się warunki, w jakich - od dzieciństwa, poprzez adolescencję, do dorosłości - młody człowiek kształtuje swoje poczucie wartości i społeczną tożsamość, a także jakiego wsparcia doświadcza ze strony wprowadzającego w świat społecznych wartości środowiska. Potrzeba wsparcia społecznego (ze strony rodziny i znaczącego środowiska życia) jest jednym $\mathrm{z}$ warunków poradzenia sobie z po-

\footnotetext{
${ }^{3}$ Takie rozumienie kryzysu obecne jest w interpretacjach E.H. Eriksona. Szerzej m.in. Witkowski, 2009; Opoczyńska 1995: 63.
} 
jawiającymi się zjawiskami kryzysowymi we wszystkich obszarach, które wyznaczają czas i społeczne miejsce młodego człowieka ${ }^{4}$. Adolescent ma do pokonania długą drogę, by znaleźć grupę, która jest mu bliska i z którą się utożsamia. Jego dorastanie, obserwowane $\mathrm{w}$ różnych sytuacjach społecznych, nie jest wolne od procesu przechodzenia z jednej fazy życia do kolejnej, obciążonych wieloma potencjalnymi kryzysami. Proces dorastania do zadań dorosłego życia jest permanentnym pokonywaniem owych kryzysów, generowanych na drodze konfliktów indywidualnych i społecznych, na skutek poszukiwania siebie i swojego miejsca w świecie. Kształtowaniu indywidualnej tożsamości towarzyszy bowiem zachwianie pewności siebie, dezorientacja i swoista labilność, co sprzyja rodzeniu się konfliktów z samym sobą oraz znaczącymi osobami w ważnych obszarach życia. Między innymi ze względu na ową labilność młodzieży o wiele trudniej niż osobom dorosłym funkcjonować w relacjach społecznych, wymagających dostosowania. Ważne jest, by w procesie tej społecznej komunikacji nie zabrakło uważności bliskich osób na priorytetowe potrzeby młodzieży i młodych dorosłych w zakresie podejmowania samodzielnych decyzji i zobowiązań dotyczących własnego życia, wyrażanych wzrostem odpowiedzialności za siebie i swoje wybory. Zanim rozwiną się te nowe momenty zaradności, młodzi ludzie napotykają na liczne trudności codziennego życia, generujące indywidualnie przeżywane sytuacje kryzysowe. Wiążą się one z funkcjonowaniem w sieci związków społecznych, w których zmienia się status młodego człowieka. Dlatego ważne jest, by wsparcie miało wartość emocjonalno-instrumentalną i wolne było od uwikłania w społecznie szkodliwe dla rozwoju autonomicznej tożsamości statusy zależności od rodziców i innych - wpływowych - dorosłych.

Warto w tym miejscu wspomnieć, że młody dorosły na ogół umiejscowiony jest już w sieci owych związków, nie poszukuje więc - jak miało to miejsce w okresie adolescencji - grupy odniesienia; zwykle ją ma. Sprawia to, że zmienia się jego rola w relacji z innymi. Często z pozycji podporządkowanej lub uprzywilejowanej wchodzi w nowe relacje, w których udziela wsparcia innym i z wymiaru osobistego przenosi je także na inne sfery swojego życia. W codziennych, wymagających konsekwencji i dojrzałości działaniach weryfikuje i koryguje swoje dotychczasowe wyobrażenia o dorosłości. Można by zatem powiedzieć, że faza wczesnej dorosłości to - w całym cyklu życia - czas specyficznie pojmowanej wrażliwości, a zarazem gotowości do inwestowania w siebie i społecznego uczenia się ${ }^{5}$ Zanim ten etap nastąpi, młody człowiek podjąć musi wiele działań

\footnotetext{
${ }^{4}$ Czas i społeczne miejsce młodego człowieka mają przynajmniej dwa wymiary: fizykalny i psychologiczny. Szerzej na ten temat: Nosal, 2004.

${ }^{5}$ Uczenie się w tym miejscu rozumiane jest w aspekcie permanentnym - jako proces całożyciowej edukacji, służący uczeniu się.
} 
w trosce o psychiczną niezależność. Jej brak ograniczać może proces kształtowania się własnej tożsamości. Zależność od innych może się rozwijać, a następnie być pielęgnowaną w sytuacji, gdy młody człowiek (szczególnie na etapie wczesnej dorosłości) pozwala - wbrew sobie - innym kierować swoim życiem. Zamiast przejąć ster kształtowania odpowiedzialnego życia i rozwoju, ważne sprawy pozostawia do rozwiązania rodzicom bądź innym osobom. Zdarza się, że w życiu mają miejsce sytuacje, w których - z powodu utrwalonych schematów rodzinnych - młody dorosły nie ma dużego wyboru, a jednocześnie boi się zmian. Wówczas, wypełniając oczekiwania swoich rodziców, na długi czas pozostaje w permanentnej od nich zależności (współzależności). W sposób naturalny taka zależność od rodziców przenosi się na inne ważne i silne osoby, na których tej młodej osobie zależy, a jego mechanizmy niezwykle silnie się utrwalają. Wówczas znajduje się w sytuacji, w której - kryjąc swoją indywidualność i rozwój autonomii w relacji opartej na zależności - nie rozwija swojej autonomii; często też ulega manipulacji z zewnątrz. Nabywanie i rozwój zależności od innych okazuje się głębokim, nieuświadomionym procesem. Wywoływanie tego stanu staje się modelem postępowania, które ma swoje źródła w dzieciństwie, kiedy z konieczności dziecko zmuszone było wejść w rolę uległą wobec autorytetów. Ten model zachowania trwa, dopóki osoba nie uświadomi sobie istnienia kryzysu w związku z tą sytuacją i nie podejmie pracy nad jego rozwiązaniem. Choć proces nabywania i rozwoju zależności od rodziców jest przypadkiem szczególnym ze względu na uwarunkowania temporalne w obszarze emocjonalnym i społeczno-ekonomicznym, przykładów podobnych zależności społecznych jest wiele. Mogą być one zakotwiczone $\mathrm{w}$ relacjach $\mathrm{z}$ rówieśnikami, także $\mathrm{w}$ środowisku edukacyjnym, niepozbawionym mechanizmów siły i rywalizacji, które sprzyjają odrzuceniu z powodu nierównych szans. Wówczas osoby słabsze, w obawie przed odrzuceniem, łatwo stają się uległymi, rozwijając tym samym konformizm w większości relacji (czasem nawet wszystkich relacjach), które są dla nich znaczące.

Analiza literatury przedmiotu (Ziółkowska, 2005: 423-468) pozwala wskazać pewne - zindywidualizowane przez cele społeczne i edukacyjne $\mathrm{w}$ adolescencji i wczesnej dorosłości - granice kształtowania się i rozwoju potrzeby autonomii. Różnice te na ogół uwidoczniają się w obszarach ważnych zadań rozwojowych ${ }^{6}$, będących odpowiedzią na ważne potrzeby osobiste, a także oczekiwania środowiska. Związane są najczęściej z różnymi obszarami samorealizacji, w tym także

\footnotetext{
${ }^{6}$ Zadania rozwojowe to ważne zadania realizowane na każdym z etapów życia, począwszy od okresu wczesnego dzieciństwa, po okres późnej dorosłości. Każde z nich obejmuje rozwój ważnych dla jednostki w określonym wieku umiejętności i kompetencji. Szerzej na ten temat m.in. Szczurek-Boruta, 2008: 709-713, 35-48.
} 
potrzebą podnoszenia swoich umiejętności. Dotyczą zatem naturalnych na tym etapie życia przestrzeni, w jakich funkcjonuje młody człowiek: kontaktów i relacji interpersonalnych (kontaktów z rodzicami, rówieśnikami, nauczycielami, innymi osobami), relacji $\mathrm{w}$ związkach partnerskich, zadowolenia $\mathrm{z}$ siebie (w aspekcie samorealizacji, statusu zdrowia i kondycji psychofizycznej), wreszcie także - co niezwykle ważne w tej fazie życia - zadowolenia $\mathrm{z}$ realizowanej edukacji i dokonywanych wyborów. Wybory edukacyjne wyznaczane są różnymi czynnikami. Wśród nich wymienić można: zainteresowania młodych ludzi, rozwiniętą potrzebę planowania/projektowania swojej przyszłości, w tym celu także obserwowanie rozwoju i wyborów edukacyjnych znanych osób, będących wzorem czy autorytetem. W wielu przypadkach wybory te okazują się samodzielne; czasami są efektem obserwacji innych, czasami też miewają charakter społeczno-ekonomiczny. Można w tym miejscu zastanowić się i zadać pytanie: czy wybór ścieżki kształcenia na poziomie szkoły średniej bywa w życiu nastolatka mniej autonomiczny niż wybór drogi dalszego kształcenia - na poziomie uzupełniającym wykształcenie średnie bądź etapie studiów? Z pewnością samorealizacja na etapie kształcenia na poziomie szkoły średniej - liceum czy technikum - obejmuje kształtowanie i rozwój predyspozycji wzmacniających poczucie sensu własnej edukacji. Można by się spodziewać, że odczuwanie zadowolenia $\mathrm{z}$ tego etapu sprzyja dokonywaniu kolejnych wyborów, nie zakłócając rytmu kształtowania się tożsamości za pośrednictwem społecznej roli „bycia uczniem”. Sprzyjać to może kontynuowaniu kształcenia $\mathrm{w}$ preferowanym kierunku. Zdarza się jednak, że zarówno na etapie późnej adolescencji, jak i wczesnej dorosłości wybory nie są jeszcze w pełni autonomiczne; czasami podyktowane bywają sugestiami innych osób, czasami są też świadectwem kontynuowania tradycji rodzinnej. Trudność odnalezienia się w tych różnych sytuacjach sprawia, że poszukujący swojej indywidualności i kompetencji młody człowiek doświadcza wewnętrznego konfliktu. Konflikt ten, jakże często utożsamiany z Eriksonowskim kryzysem tożsamości, oznacza moment przesilenia, dezorganizujący aktywność jednostki. Wówczas młodzi ludzie, nie mając odpowiedniej gotowości społecznej do podejmowania samodzielnych decyzji i działania, potrzebują wsparcia środowiska, by łatwiej dokonywać samodzielnych wyborów, tym samym także świadomie budować swoją biografię. Niezwykle ważne wydaje się, by wsparcie polegało na dostarczeniu - przez bardziej dojrzałych i zaradnych - wiedzy o sposobach bądź formach poradzenia sobie z problemem, by dostarczało młodzieży nowych okazji do przekonania się o własnej zaradności oraz okazji do permanentnego jej ćwiczenia w praktyce.

Analizując sytuację młodych dorosłych, odnosi się wrażenie, że bardziej świadomie niż adolescenci dokonują swoich wyborów i mniej emocjonalnie przeżywają decyzje o zmianach, które wprowadzają w życie. Praktyka dnia codziennego weryfikuje te przypuszczenia i obserwacje, wskazując na zróżnicowany przebieg 
zdarzeń w przypadku obu grup wiekowych. Młodzi dorośli mają z pewnością inny zakres doświadczeń, większą świadomość własnych potrzeb i mniejszy lęk przed świadomym eksperymentowaniem niż adolescenci, co sprawia, że łatwiej przychodzi im podejmować takie decyzje, których skutki starają się częściowo przewidzieć. Młodym dorosłym potrzebne jest również wsparcie emocjonalne, by łatwiej pokonać pojawiające się kryzysy. Taką priorytetową rolę, chroniącą przed ryzykiem społecznego odrzucenia, w kreowaniu świata wartości i dostarczaniu wzorów społecznego funkcjonowania w sytuacjach kryzysowych odgrywają ważne środowiska, począwszy od rodziny, przyjaciól, po nowe osoby znaczące i autorytety, a także instytucje, w których funkcjonują, i z których pomocy korzystają. W tym okresie niezwykle ważną rolę - zarówno chroniącą, jak i wyzwalającą energię do działania - odgrywa także życiowy partner. Można by pokusić się o stwierdzenie, że pomoc miewa swój zakres i hierarchiczność. O ile adolescentom w wyborach edukacyjnych bardziej skłonni są pomagać rodzice ${ }^{7}$ w przypadku młodych dorosłych choć zdecydowanie utrzymują oni nadal status autorytetu - mają słabszy wpływ na ich decyzje dotyczące wyboru dalszych etapów kształcenia i rozwoju ${ }^{8}$. Wydaje się to społecznie dość oczywiste ze względu na wzrastającą rolę relacji przyjacielskich i bliskich relacji partnerskich w tym okresie życia. Na tendencje takie wskazują zarówno potoczne obserwacje życia społecznego, jak i wyniki badań prowadzonych wśród młodych ludzi w obu kategoriach wiekowych. Korzystanie z określonych form pomocy ze strony rodziców jest także kwestią indywidualną, zależną od systemu wsparcia, który towarzyszył temu młodemu człowiekowi przez całe jego dotychczasowe życie. Ważne jest nie tylko to, jakiego rodzaju wsparcia oczekuje (i oczekiwał w przeszłości) młody człowiek, ale - w głównej mierze - to, jak pojmują (i pojmowali) wsparcie i pomoc jego rodzice. Czasami zdarza się bowiem, że potocznie rozumiane wsparcie rodziców/rodziny przeradza się w znaczne od ich pomocy uzależnienie. Ma wówczas charakter przewlekły i uniemożliwia kształtowanie się autonomicznej osobowości młodego człowieka w ważnych, a nawet decydujących rozwojowo momentach życia. Rodzice - mając wcześniej stały wgląd w potrzeby swojego dorastającego dziecka - nabywają niejako naturalne prawo do stałej kontroli, z której sami często nie potrafią zrezygnować. Kontrola i odpowiedzialność rodzicielska za dorosłe dziecko może się przyczynić do ograniczenia rozwoju jego dojrzałej tożsamości, utrwalając poziom pozostawania w stanie per-

\footnotetext{
${ }^{7}$ Wskazują na to wyniki badań prowadzonych wśród uczniów szkół średnich na Podbeskidziu; byli to licealiści i uczniowie technikum. Szerzej uzyskane wyniki badań empirycznych prezentowane są w opracowaniu: Suchodolska 2016.

${ }^{8}$ Wnioski takie mają swoje uzasadnienie w analizach materiału badawczego, realizowanego wśród młodych dorosłych studiujących na Śląsku (studentów Uniwersytetu Śląskiego i Uniwersytetu Ekonomicznego), w ramach prowadzonych przez autorkę szeroko zakrojonych badań indywidualnych i zespołowych w roku akademickim 2015/2016. Por. przypis 9 w tym opracowaniu.
} 
manentnej semiautonomii. Dlatego ważne jest, by młody człowiek potrafił w porę przerwać trans zależności od rodziców i innych osób w najbardziej dla niego decydującym momencie, wartościowym z punktu widzenia „własnego interesu” $\mathrm{w}$ rozwoju emocjonalnej autonomii. Jest to szczególnie potrzebne w obszarach ważnych zadań rozwojowych, które zmieniają swój status na bardziej dojrzały. Wówczas zmieniają się także ważne punkty odniesienia i identyfikacji społecznej. Przykładem jest zmiana pozycji przyjaciół oraz partnera życiowego na bardziej priorytetową niż dotąd, co powoduje także zmiany w hierarchicznym układzie środowiskowych odniesień, niezbędne do uzyskania dojrzałej tożsamości (zarówno indywidualnej, jak i społecznej). Uświadomienie sobie tych etapów przez młodego człowieka i praca nad rozwojem niezależnej tożsamości, a tym samym także rozwojem odpowiedzialności za siebie, jest równoznaczna z podjęciem próby rozwiązania kryzysu.

W opracowaniu zaprezentowano materiał empiryczny pochodzący z badań zespołowych prowadzonych na Śląsku Cieszyńskim przez pracowników Zakładu Pedagogiki Społecznej i Edukacji Międzykulturowej Wydziału Etnologii i Nauk o Edukacji Uniwersytetu Śląskiego w Cieszynie w ramach projektu Edukacja dzieci, młodzieży $i$ dorostych $w$ społecznościach zróżnicowanych kulturowo, realizowanego w roku 2016 pod kierunkiem naukowym Aliny Szczurek-Boruty. Ponadto, grupę studentów stanowili młodzi dorośli studiujący na Śląsku - na uniwersytetach. Grupa ta liczy 700 osób i jest częścią większej grupy studentów, ujętych w badaniach indywidualnych autorki. Wyniki badań dotyczą zatem grupy młodzieży i młodych dorosłych (w wieku 17-19 lat oraz 22-26 lat). Zgromadzony materiał badawczy poddany został weryfikacji z wykorzystaniem metod ilościowego i jakościowego opisu badań. Prezentowane w tym opracowaniu wyniki badań empirycznych stanowią jego część i odzwierciedlają jedynie analizę ilościową opracowanych.

Uzyskane w wyniku prowadzonych badań dane pozwalają zauważyć, że cały okres młodości na ogół nie jest wolny od kryzysów. Sytuacje kryzysowe towarzyszą młodym ludziom w różnych obszarach życia; dotyczą różnych poziomów ich zaangażowania $\mathrm{w}$ społeczne relacje oraz etapy edukacji. Są oni tego świadomi i przyznają, że poczucie bycia w kryzysie nie jest im obce. Obecność kryzysów deklaruje $77 \%$ - w przedziale 22-25 lat. Generalnie, przeżywane kryzysy zarówno w przypadku młodzieży, jak i młodych dorosłych mają podobne podłoże emocjonalno-społeczne. $\mathrm{W}$ grupie młodzieży wiążą się z przeżywanymi emocjami w obszarze samooceny, relacji z rodzicami/rodziną, płcią przeciwną, poczuciem własnej wartości i sensu życia.

Analizując wypowiedzi badanej młodzieży, można wskazać, że przeżywany przez nią niepokój i doświadczanie kryzysu umiejscowione są odpowiednio w: relacjach z rodzicami i rodzeństwem (54\%), innymi osobami $\mathrm{w}$ rodzinie (11\%), następnie relacjach w związku wczesno miłosnym (25\%) oraz - ich aktualnej 
sytuacji ekonomicznej - a dokładniej - deklarowanym przez młodzież braku pieniędzy (19\%) i trudnościach wyboru własnej drogi życiowej (22\%). Młodzież koncentruje się na podaniu powyższych obszarów kryzysów w kolejności uwzględniającej obszary, z którymi ma ona mniej doświadczeń bądź w których jest bardziej emocjonalna lub/i gorzej sobie radzi. Ponadto, w dobie konsumpcyjnego społeczeństwa deklaruje brak pieniędzy, który może być związany z sytuacją ekonomiczną w rodzinie, indywidualnymi wyobrażeniami lub oczekiwaniami (często też z powodu wygórowanych potrzeb i wyszukanych oczekiwań, kreowanych przez media, modę, kulturę Fast ${ }^{9}$, bądź promowany przez media kult społeczeństwa konsumpcji). Ponadto, właśnie w adolescencji wzrasta apetyt na eksponowanie swojej osoby przez pryzmat kategorii „być czy mieć” (Szawiel, 1998: 169-188), gdzie w przypadku współczesnej młodzieży model zachowań społecznych potencjalnie wydaje się, że wskazuje ukierunkowanie na „mieć” ${ }^{\text {, }}$ a rzeczywistość kulturowa jest przez nią identyfikowana z kulturą popularną we wszelkich jej wymiarach ${ }^{11}$. Poruszane kwestie ilustruje ryc. 1.

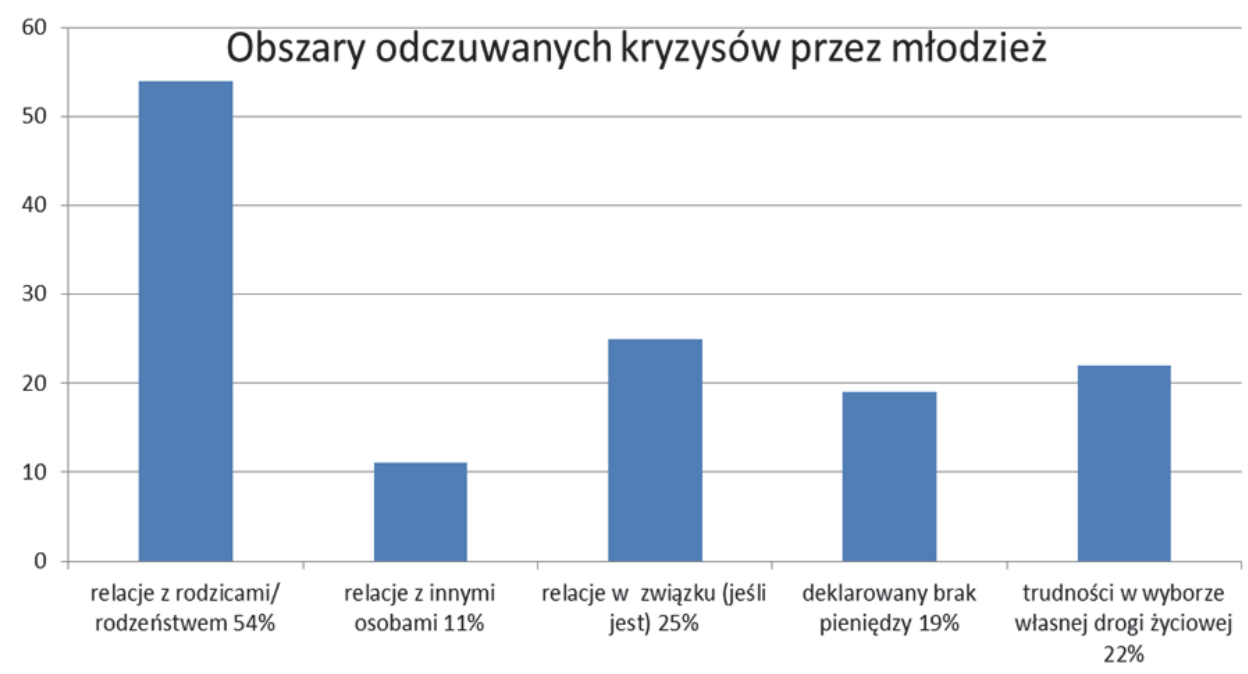

Ryc. 1. Obszary odczuwanych kryzysów przez młodzież. Źródło: badania własne

${ }^{9}$ Cechy Kultury Fast i jej oddziaływanie opisywane jest szerzej przez Z. Melosika; por. Z. Melosik, 2003: 19-37.

${ }^{10} \mathrm{~W}$ tym względzie spostrzeżenia poczynione wobec młodzieży są podzielone. Obserwacje zachowań społecznych młodych ludzi (szczególnie adolescentów) mogą wielokrotnie prowadzić do opinii, że młodzież jest ukształtowana we wzorcu zachowań mocno konsumpcyjnych. Na podstawie prowadzonych badań empirycznych niektórzy autorzy opracowań wskazują jednak bardziej na aktywność orientacji „być” niż „mieć” w systemie wartości młodzieży. Por. m.in. Myszka, 2013: 149.

${ }^{11}$ Szerzej na ten temat m.in. Melosik, 2013: 141-154. 
Młodzież skarży się głównie na osamotnienie w swoich sprawach (34\%), niskie poczucie własnej wartości (33\%), mało satysfakcjonujące/dalekie od oczekiwanych relacje z płcią przeciwną (22\%), także z rodzicami (18\%); zgłasza też problemy poczucia sensu życia $(11 \%)^{12}$ - między innymi w związku z osłabieniem motywacji do działania $w$ sytuacjach trudnych i problemowych, owym niespełnieniem we wczesnych związkach miłosnych, niezadowoleniem $\mathrm{z}$ wybranej szkoły oraz niepewnością związaną z dalszymi wyborami życiowymi. Przykłady te nie są odosobnione; wielu młodych ludzi na etapie adolescencji miewa takie problemy, nie są one niczym zaskakującym. Uznać je można za naturalne, związane z dojrzewaniem i stopniowym tworzeniem własnej bazy tożsamościowej, w której sprowokowane przez codzienność kryzysy okazują się potrzebne, a ich rozwiązywanie pełni funkcję środka doskonalącego osobowość. Ponadto, rzeczywistość, którą opisuje i ocenia młodzież, jawi się dziś jako mało przyjazna, czy wręcz „niepozytywna”. Pomimo takich społecznie wykreowanych obrazów i przeżywanego kryzysu mentalnościowego i społecznego - jak wskazują autorzy prowadzący badania nad młodzieżąa ${ }^{13}$ - młodzi ludzie odnajdują swoje miejsce w ambiwalentnej i mało przewidywanej rzeczywistości, tworząc względnie spójne i dojrzałe identyfikacje.

Warto $\mathrm{w}$ tym miejscu wspomnieć, że młodzież nie deklaruje potrzeby wyzwolenia się z więzów zależności z rodzicami. Relacje te są dla niej ważne, a sami rodzice ważnym źródłem wsparcia. Często jednak obecność nagromadzonych na tym etapie życia kryzysów przekracza możliwości zaradności psychicznej jednostki i wymaga dostarczenia konkretnej formy pomocy. Zależy ona od preferencji i oczekiwań, jakie ma aktualnie młody człowiek, jednak w części przypadków wymaga profesjonalizmu pomagających. Pomimo że - generalnie - młodzież oczekuje pomocy od rodziców (82\%), innych osób w rodzinie $(33 \%)$ i przyjaciół (35\%), nie zawsze jest ona wystarczająca. Często potrzeby młodych ludzi ulokowane są w środowiskach o określonej duchowości w atmosferze wzajemnych relacji - adresowane do realizowania się w ruchach religijnych, oazowych, kościelnych, także stowarzyszeniach i instytucjach związanych z Kościołem (45\%). Pewna jej część potrzebuje pomocy profesjonalistów, w tym - jak deklaruje - psychologa (34\%), psychoterapeuty (22\%) czy psychiatry (13\%), z których pomocy korzysta. Jak wskazuje praktyka w zakresie pomocy i interwencji (terapeutycznej), wielu uczniów szkoły średniej korzysta z pomocy psychologicznej, psychoterapeutycznej, a także lekarzy-psychiatrów, głównie z powodu braku zdolności uczenia się i wypoczynku, niskiej samooceny, poczucia

\footnotetext{
${ }^{12}$ Wybory w procentach nie sumują się do 100\%, ze względu na możliwość równoczesnego kilku źródeł kryzysu.

${ }^{13}$ Por. m.in. Cybal-Michalska, 2006; Myszka, 2013: 148.
} 
pustki i osamotnienia. Problemy te generują się w zróżnicowanych, nie do końca możliwych do obiektywnego zdiagnozowania warunkach, czasami także z powodu braku więzi w rodzinie, braku zainteresowania rodziców dorastającym dzieckiem i jego problemami bądź błędnego przekonania rodzica, że dorastający jeśli sam nie sygnalizuje - pomocy nie potrzebuje. Różne są też oczekiwania młodzieży w stosunku do formy wsparcia, jakiej ona potrzebuje. Wypowiedzi badanych można zagregować pod względem treści i jakościowego opisu, wyłaniając główne formy oraz sytuacje wymagające wsparcia. Młodzież od rodziców oczekuje w szczególności wsparcia emocjonalnego (82\%) - obecności i uważności na jej problemy, rozmowy i zrozumienia; w dalszej kolejności - pomocy finansowej (32\%), choć na ogół młodzież w tym wieku taką pomoc w sposób oczywisty otrzymuje i - co wydaje się ciekawe - zaprzeczając wcześniej zadeklarowanym problemom finansowym uważa wręcz, że jej aktualna sytuacja jest dobra. Dane te ilustruje ryc. 2.

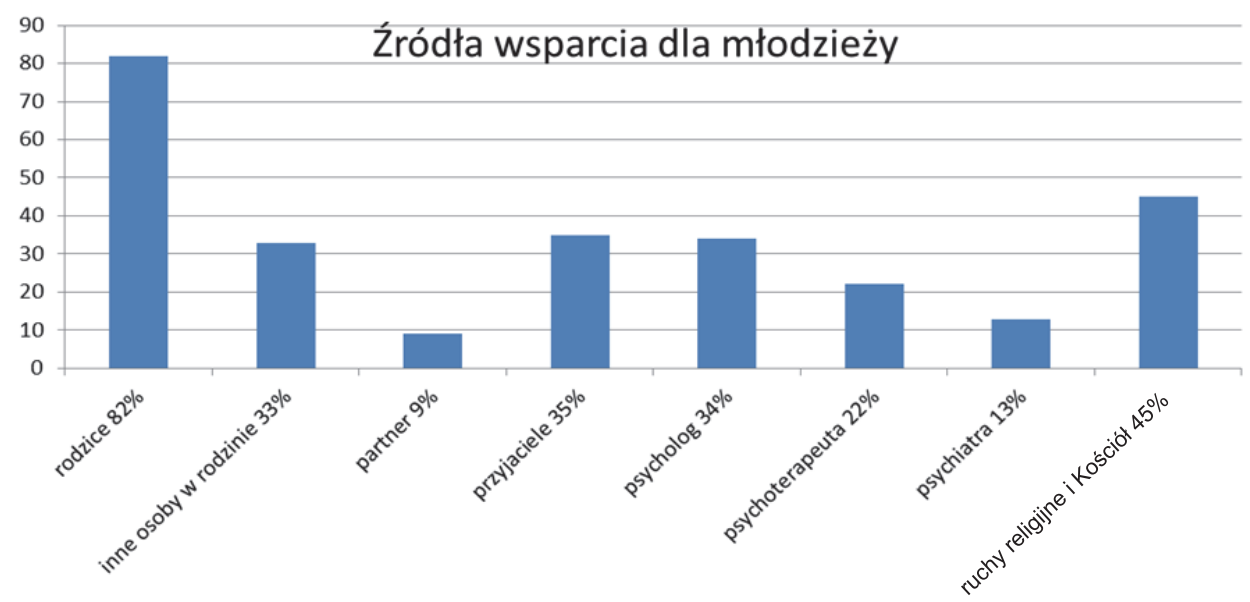

Ryc. 2. Źródła wsparcia młodzieży w trudnych sytuacjach. Źródło: badania własne

W przypadku grupy studentów kryzysy powstają głównie w związku z aktualną sytuacją kształcenia, a także - co często idzie z sobą $\mathrm{w}$ parze - $\mathrm{z}$ obawą o zatrudnienie, szanse na otrzymanie pracy (lub jej utrzymanie), samorealizację zawodową. Zdarza się, że studiujący nie są zadowoleni ze swoich edukacyjnych wyborów i właśnie dlatego towarzyszy im kryzys upływającego czasu, przy jednoczesnym braku pomysłu na siebie w niedalekiej przyszłości. Czasami kryzys towarzyszy osobie w związku z poczuciem nadmiaru obowiązków codziennego życia oraz odczuwanych problemów w zakresie zdrowia. Ta różnica w identyfi- 
kowanych grupy badanych adolescentów i młodych dorosłych sytuacjach kryzysowych potwierdza pojawienie się nowych zadań rozwojowych okresu wczesnej dorosłości, związanych z podejmowaniem aktywności zawodowej oraz odpowiedzialności za siebie i inne osoby. Wczesna dorosłość to okres dużych napięć z powodu zarówno satysfakcji i dumy z osiąganych efektów czy sukcesów, dającej energię i chęć do działania, jak i często ryzykownych decyzji - w związku $z$ apetytem na samodzielność i samowystarczalność. $Z$ drugiej zaś strony może to być czas doświadczania silnych obciążeń $\mathrm{z}$ powodu nakładających się zobowiązań w podstawowych obszarach życia. Na tym etapie rozwoju obszary te wypełniają takie zadania społeczne jak: godzenie małżeństwa/partnerstwa (czasami ról rodzicielskich) z pracą, rozwój osobisty z działaniami podejmowanymi na rzecz innych ludzi, działania zaspokajające aktualne potrzeby $\mathrm{z}$ działaniami ukierunkowanymi na przyszłość, ponadto dbałość o pozycję "Ja” i status $\mathrm{w}$ grupie $\mathrm{z}$ dobrem grupy, edukację z pracą. Ich występowanie generuje również inne potrzeby przy równoczesnym powstawaniu obiektywnych ograniczeń, takich jak: ograniczone zasoby finansowe vs dalsza edukacja lub praca zarobkowa. W obliczu powyższych zgeneralizowanych problemów dorosłość to nie zawsze komfortowy, dojrzały pod względem mechanizmów zaradności indywidualnej i społecznej okres w życiu. W tym czasie człowiek buduje także sieć wsparcia społecznego na dalsze lata. Występowanie różnic $\mathrm{w}$ doświadczanych sytuacjach kryzysowych przez grupy zróżnicowane wiekowo uznać można za naturalne, $\mathrm{z}$ uwagi na odmienne priorytety społecznego funkcjonowania i związane z nimi bardziej doj-

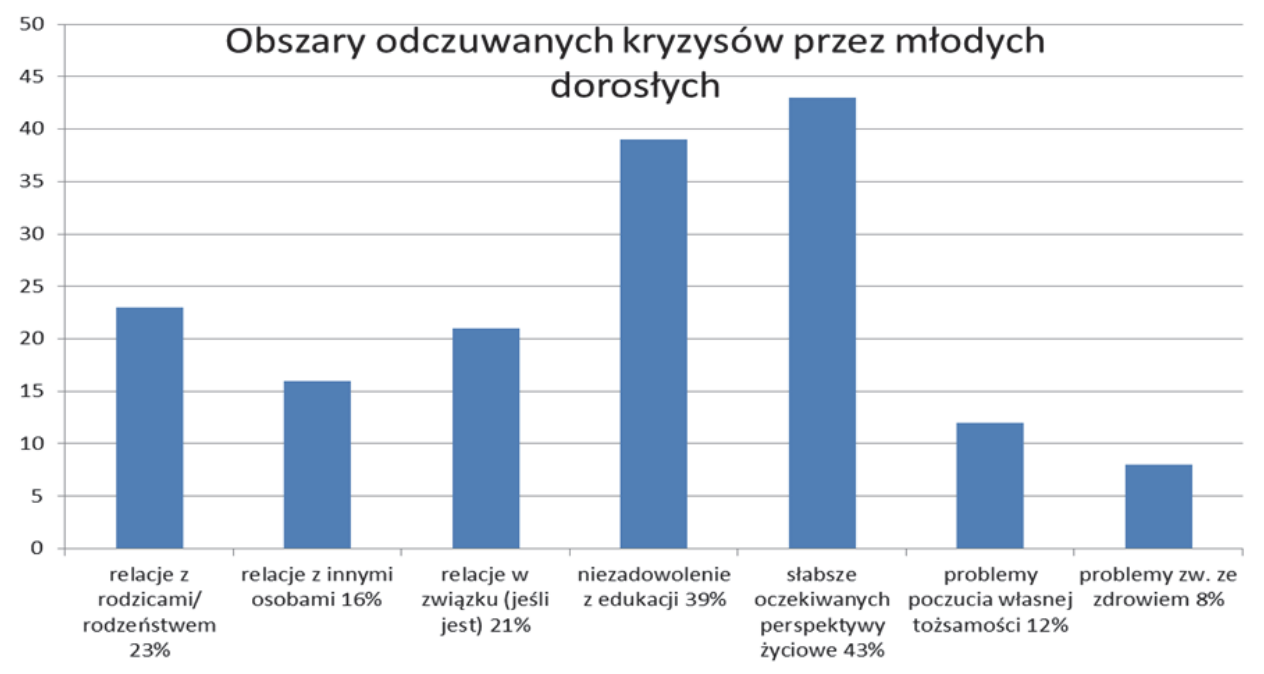

Ryc. 3. Obecność kryzysów w ważnych obszarach rozwojowych młodych dorosłych. Źródło: badania własne 
rzałe zadania rozwojowe. Zadania te obciążone są wieloma nowymi rolami społecznymi, w związku z podejmowaniem nowych ról edukacyjno-zawodowych, chęcią lub potrzebą większej samodzielności czy niezależności (nie zawsze $\mathrm{z}$ akcentem na wyłącznie własne potrzeby rozwojowe). Obecność sytuacji kryzysowych deklarowanych przez młodych dorosłych prezentuje ryc. 3.

W grupie młodych dorosłych w przedziale wieku 22-26 lat zauważa się, że kryzysy dotyczą najczęściej priorytetowych dla nich zadań rozwojowych, realizowanych $w$ takich obszarach jak: relacje interpersonalne, $w$ tym zwłaszcza relacje w związku - $21 \%$ i z rodzicami - $23 \%$ ) oraz ocena aktualnej i przyszłej sytuacji życiowej, obejmująca słabsze od oczekiwanych perspektywy życiowe (43\%), niezadowolenie $\mathrm{z}$ własnej edukacji (39\%), problemy poczucia własnej tożsamości (12\%) oraz problemy związane ze zdrowiem $(8 \%)$. W badaniach uwzględnieni zostali młodzi dorośli, którzy kontynuują edukację i funkcjonują w związkach partnerskich. Wskazanie wyżej wymienionych źródeł, w których powstawać mogą najczęściej odczuwane sytuacje kryzysowe, nie dziwi, a nawet może wydawać się oczywiste. Nowe wyzwania, przed którymi stoją młodzi dorośli, generujące konieczność dokonywania licznych wyborów w permanentnie zmieniających się warunkach społeczno-ekonomicznych, a także ryzyko niepowodzeń, stając się źródłem wielu napięć i lęków o własną przyszłość. Zgłaszają oni obecność kryzysów także w obszarach ważnych zadań rozwojowych, sytuując je głównie w konfrontacji z realizowaną drogą życiową na poziomie edukacji (39\%) i przyszłej pracy $(43 \%)^{14}$, w relacjach rodzinnych i partnerskich $(25 \%)$, innych relacjach społecznych (16\%). Można pokusić się o stwierdzenie, że ten nieomal hierarchiczny układ, stanowiący ważny łańcuch spraw w życiu dorosłego człowieka, uświadamia, że kryzysy powiązane są $\mathrm{w}$ świadomości badanych $\mathrm{z}$ uznawanymi wartościami, a także potrzebami usamodzielnienia się. Wśród źródeł kryzysu wymieniają oni - obok wyżej wspomnianych - problemy odczuwane na poziomie zdrowia, poszukiwania pracy oraz budowania własnej tożsamości. Pojawianie się tych kategorii $\mathrm{w}$ wypowiedziach młodych dorosłych świadczyć może o większej ich dojrzałości oraz bardziej świadomym podejściu do swojej kondycji psychospołecznej i zdrowotnej u progu realizowania etapu życia, który wymaga od nich większej odpowiedzialności i konsekwencji, niż miało to miejsce na etapie dorastania. Warto $\mathrm{w}$ tym miejscu wspomnieć, że młodzi ludzie (zarówno adolescenci, jak i młodzi dorośli) nie deklarują potrzeby wyzwolenia się z więzów zależności z rodzicami. Relacje z rodzicami są dla nich ważne,

\footnotetext{
${ }^{14}$ Praca traktowana jest przez młodych ludzi w kategoriach aksjonormatywnych - jako szansa na udane życie i osiągnięcie pożądanego stanu, a nawet jego warunek. Całkiem prawdopodobne, że dzieje się tak z powodu bezwzględnego wymogu powszechnej aktywności zawodowej, która umożliwia pozyskanie i rozwój kapitału niezbędnego do osiągnięcia samodzielności i niezależności życiowej.
} 
a sami rodzice ważnym źródłem wsparcia. Często jednak obecność nagromadzonych na tym etapie życia kryzysów przekracza możliwości psychiczne jednostki i wymaga dostarczenia konkretnej formy pomocy. Zależy ona od preferencji i oczekiwań, jakie ma aktualnie młody człowiek; zdarza się, że młodzi dorośli potrzebują pomocy instytucjonalnej, o prawnych podstawach i znamionach profesjonalizmu świadczonych usług.

W przypadku młodych dorosłych rysuje się duże podobieństwo preferowanych/wymienionych źródeł wsparcia. Podobnie jak w przypadku młodzieży, ważne jest środowisko rodzinne (rodzice/inne osoby w rodzinie); ponadto $\mathrm{w}$ tej grupie wiekowej obok wyżej wymienionych środowisk wspomagających duchowo w trudnych sytuacjach życiowych - wzrasta rola przyjaciół i ranga partnera życiowego. Na pomoc rodziców - obok wsparcia emocjonalnego (68\%) - młodzi dorośli liczą $\mathrm{w}$ aspekcie pomocy finansowej (56\%) - w tym mieszkaniowej oraz innych w trudnych sytuacjach życiowych. Od partnera (pod warunkiem, że go mają) oczekują - w głównej mierze - wsparcia emocjonalnego w każdej sytuacji życiowej (89\%), zwłaszcza w przypadku braku pieniędzy czy braku pracy. Związek partnerski jest dla nich synonimem małżeństwa i rodziny; z przejęciem przez drugą osobę współodpowiedzialności za partnera, losy związku i jego powodzenie. To dojrzałe, ale i bardzo wymagające oczekiwania, wzrastające wraz $\mathrm{z}$ wiekiem badanych. Ta deklarowana postawa - ze względu na wymagania i stopień zaangażowania $\mathrm{w}$ planowanie przyszłości z partnerem różnicuje badane grupy adolescentów i młodych dorosłych. $\mathrm{W}$ adolescencji bowiem we wczesnych związkach obserwuje się laminarny wzrost współodpowiedzialności na poziomie życia uczuciowego partnerów, jednak niekoniecznie z przejęciem odpowiedzialności za obustronne ich wybory i decyzje. We wczesnej dorosłości człowiek osiąga psychiczną i nierzadko również finansową autonomię. Wówczas formułuje ważne cele, często wspólnie z partnerem, poza domem rodzinnym. Wszystkie te wczesne projekty mają swoje konsekwencje w przyszłości; mogą stanowić podstawę do osiąganej satysfakcji z własnych wyborów, w których swoje uprzywilejowane miejsce mają także wybory i odpowiedzialność partnera życiowego. Dla innych młodych dorosłych ważny jest rozwój bycia samosterownym i niezależnym od najbliższego środowiska (w tym czasami także od partnera). Bez względu na cele indywidualne, wiązane $\mathrm{z}$ byciem w związku, wymiar oczekiwań wobec bliskich osób, z którymi planują oni dzielić swoje życie, różni się od pełnych młodzieńczej fascynacji i uniesień relacji partnerskich w adolescencji.

W dalszej kolejności - w społecznej przestrzeni pomocy i wsparcia - młodzi dorośli wymieniają także ruchy, stowarzyszenia i organizacje religijne oraz kościelne (36\%), a także instytucje wspierające materialnie, dostarczające pomocy o charakterze społeczno-prawnym i ekonomicznym. Te ostatnie to na ogół insty- 
tucje wspierające młodych dorosłych w szczególnych przypadkach losowych, takie jak: ZUS (12\%) czy MOPS (8\%). Pewna część badanej grupy wsparcia dla siebie szuka także u profesjonalistów - głównie psychoterapeutów (15\%), a także w organizacjach sportowych i studenckich ( $5 \%$ - w AZS). Ponadto wśród studiujących młodych dorosłych pojawia się pewna grupa, która otrzymuje wsparcie materialne $\mathrm{w}$ postaci stypendium (socjalnego i/lub naukowego) (26\%), również w postaci Nagrody Rektora (2\%), a także nieznaczna grupa deklaruje, że - szkoleniowo $\mathrm{i}$ instrumentalnie - korzysta $\mathrm{z}$ niej $\mathrm{w}$ Akademickim Biurze Karier $(1,5 \%)$. Preferencje te ilustruje wykres 4 .

Najczęściej oczekiwaną przez młodych dorosłych formą wsparcia jest zrozumienie i gotowość udzielania pomocy w każdej trudnej dla nich sytuacji, w szczególności problemowej/kryzysowej, na etapie trudności podejmowania ważnych życiowo decyzji, przerastających ich społeczne doświadczenie. Wielu młodych dorosłych oczekuje jednocześnie wsparcia finansowego i emocjonalnego. Będąc świadomymi trudności, z jakimi przyjdzie im się zmierzyć (na przykład problemów z otrzymaniem pracy, samodzielnego mieszkania, samodzielnego utrzymania finansowego), liczą na wsparcie partnera (89\%) i rodziców 68\%), a w sprawach duchowych - zdarza się, że oczekują pomocy od przyjaciół (45\%), dziadków (12\%) oraz różnych organizacji. Są też tacy młodzi dorośli (12\%), którzy utrzymują, że nie potrzebują i nie oczekują wsparcia lub pomocy od nikogo.

Ten sposób rozumienia i praktykowania wsparcia różnicuje także rozwój samodzielności młodych ludzi (na poziomie zewnętrznym i organizowania się osobowości), ocenę własnych umiejętności, a także ich stosunek do podejmowania różnych decyzji i pracy nad ich modyfikacjami. Z pewnością charakteryzuje

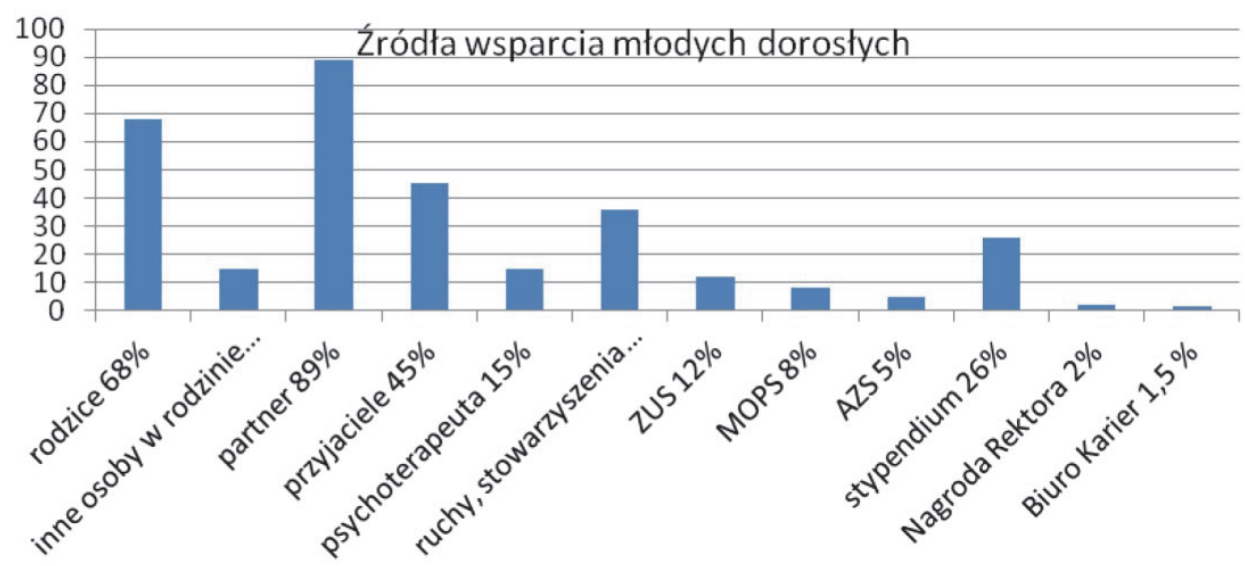

Ryc. 4. Źródła wsparcia młodych dorosłych w trudnych sytuacjach. Źródło: badania własne 
grupę młodych dorosłych świadomość kryzysów w rozwoju psychospołecznym oraz zmian, jakie zachodzą w zakresie ich potrzeb. Mają oni przekonanie, że chcą kontrolować własne życie, być sprawcami wielu zdarzeń, chcą rozwiązywać swoje kryzysy, korzystając z dostępnej pomocy. Dlatego tak ważne jest, by środowisko umożliwiło młodemu człowiekowi permanentne uczenie się i egzekwowanie od siebie samego uważności w identyfikowaniu pojawiających się sytuacji kryzysowych, a także - by dało jemu odpowiednie wsparcie.

Można sądzić, że wszelkie ważne wydarzenia we wczesnej dorosłości mają charakter bardziej aktywny i świadomy niż na etapie adolescencji. Prawdopodobnie dlatego źródłem pojawiających się kryzysów u młodych dorosłych staje się między innymi edukacja i troska o własną przyszłość zawodową w niedalekiej przyszłości. Ponieważ wizja tej przyszłości powstaje realnie właśnie na etapie świadomego zaangażowania $\mathrm{w}$ realizowaną edukację, $\mathrm{w}$ obszarze zadowolenia $\mathrm{z}$ edukacji może się pojawiać kryzys. Jest to związane $\mathrm{z}$ nieustannie rozwijającą się samoświadomością, jak również rozwojem myślenia prospektywnego i biograficznego. Może to tłumaczyć obecność kryzysu edukacji, planów i perspektyw życiowych właśnie $\mathrm{w}$ fazie wczesnej dorosłości, kiedy młody człowiek zaczyna dostrzegać realia i planować swoją przyszłość. Relacje partnerskie, mające wówczas również bardziej dojrzałe podłoże psychospołeczne niż w adolescencji, stają się dla młodych dorosłych ważnym źródłem oczekiwań związanych z przyszłością. Nie jest wykluczone, że prawdopodobnie dlatego różnią się deklaracje badanych grup wiekowych $\mathrm{w}$ zakresie oczekiwanej pomocy od najbliższych, gdzie - w przypadku młodzieży - są to rodzice (82\%), a w przypadku młodych dorosłych - w głównej mierze - życiowy partner (89\%).

Analiza materiału badawczego pozwala stwierdzić, że zarówno młodzież, jak i młodzi dorośli wykazują postawę dojrzałą wobec obserwowanych w swoim życiu kryzysów. Z czujnością też identyfikują ich źródła, sytuując je w obszarach relacji ze światem i samym sobą. To ważna umiejętność, ułatwiająca rozwój osobowości dojrzałej, o kompetencjach podmiotowych - na poziomie samostanowienia o sobie i kształtowania spójnej dojrzałej tożsamości. Ta świadomość potrzeby rozwoju swoich zasobów, a także trudności w budowaniu pozycji wyznaczanej dorosłością, zawiera w sobie elementy kreujące także niezależną tożsamość. Za niezwykle wartościową uznać można zatem dobrą orientację nie tylko młodych dorosłych, ale i adolescentów, w swoich potrzebach, zakresach ich realizacji oraz deficytach odzwierciedlających trudności w realizowaniu zadań rozwojowych. Ich znajomość, jak również aktywne uczestniczenie w komunikacji społecznej w środowisku życia stają się ważnymi komponentami wyznaczającymi poczucie niezależności, wyznaczającymi status własnej tożsamości i bycia dojrzałym członkiem społecznych grup odniesienia. 


\section{Literatura}

Badura-Madej M. (1999). Wybrane zagadnienia interwencji kryzysowej. Poradnik dla pracowników socjalnych. Katowice.

Bardziejewska M. (2004). Okres dorastania. Jak rozpoznać potencjał nastolatków. [W:] A.I. Brzezińska (red.). Psychologiczne portrety człowieka. Gdańsk.

Bauman T. (1998). O możliwości zastosowania metod jakościowych $w$ badaniach pedagogicznych. [W:] T. Pilch. Zasady badań pedagogicznych. Warszawa.

Brzezińska A.I. (2005). Psychologiczne portrety człowieka. Gdańsk.

Cybal-Michalska A. (2006). Tożsamość młodzieży w perspektywie globalnego świata. Studium socjopedagogiczne. Poznań.

Downs A. (2007). Jak przezwyciężyć życiowy kryzys. Gdańsk.

Griese H.M. (1996). Socjologiczne teorie młodzieży. Kraków.

James R.K., Gilliland B.E. (2008). Strategie interwencji kryzysowej. Warszawa.

Kubacka-Jasiecka D. (2007). Interwencja kryzysowa z perspektywy psychosocjokulturowego paradygmatu kryzysu. Kielce.

Lewowicki T. (red.). (1994). Poczucie tożsamości narodowej młodzieży - studium z pogranicza polsko-czeskiego. Cieszyn.

Łobocki M. (2010). Wprowadzenie do metodologii badan pedagogicznych. Kraków.

Melosik Z. (2003). Edukacja, młodzież i kultura wspótczesna: kilka uwag o teorii i praktyce pedagogicznej. „Chowanna” nr 1.

Melosik Z. (2013). Kultura popularna i tożsamość młodzieży. W niewoli władzy i wolności. Kraków.

Myszka L. (2013). Autoidentyfikacje współczesnej młodzieży - przyczynek do dyskusji na temat: Młodzież czyli kto? „Kultura - Społeczeństwo - Edukacja” nr 2(4).

Nosal Cz.S. (2004). Czas psychologiczny: wymiary, struktura i konsekwencje. Warszawa.

Oles P.K. (2012). Psychologia człowieka dorosłego. Ciągłość - zmiana - integracja. Warszawa.

Opoczyńska J. (1995). Moratorium psychospołeczne - szansa czy zagrożenie dla rozwoju. (Refleksje nad koncepcja rozwoju E.H. Eriksona). [W:] A. Gałdowa (red.). Wybrane zagadnienia z psychologii osobowości. Kraków.

Sinczuch M. (2002). Wchodzenie $w$ dorosłość w warunkach zmiany społecznej. Warszawa.

Suchodolska J. (2017). Kryzys w rozwoju psychospołecznym młodzieży - potrzeba wsparcia rodzinnego i środowiskowego. [W:] B. Chojnacka, A. Gancarz (red.). Szkoła, rodzina, środowisko lokalne. Dobre praktyki wspierania rozwoju, aktywizacji i integracji społecznej (w druku).

Szawiel T. (1998). Urzeczeni przez rynek? Stosunek młodzieży do rynku, pieniądza i pracy. „Kultura i Społeczeństwo" nr 1.

Szczurek-Boruta A. (2008). „Zadania rozwojowe” jako kategoria pedagogiczna - wykorzystanie i perspektywy. [W:] R. Wawrzyniak-Beszterda (red.). Wokół zagadnień wychowania - aspekty teoretyczne i przyczynki empiryczne. „Zeszyty Naukowe Młodych Pedagogów przy Komitecie Nauk Pedagogicznych Polskiej Akademii Nauk".

Szczurek-Boruta A. (2008). Zadania rozwojowe. [W:] Encyklopedia pedagogiczna XXI wieku. T. VII: V-Ż, Warszawa.

Witkowski L. (2009). Rozwój i tożsamość w cyklu życia. Studium koncepcji E.H. Eriksona. Łódź.

Ziółkowska B. (2005). Okres wczesnej dorosłości. Jak rozpoznać potencjat młodych dorostych? [W:] A.I. Brzezińska (red.). Psychologiczne portrety człowieka. Gdańsk. 
